\title{
Informal recyclers' geographies of surviving neoliberal urbanism in Vancouver, BC
}

\author{
Abstract \\ Based on our study of informal recyclers' experiences of well-being, we draw on \\ "geographies of survival" to understand the challenges that these informal workers experience in \\ a context of urban change in Vancouver, BC. This concept explains that impoverished city \\ residents construct pathways through the urban landscape that provide shelter, access to food, \\ spaces of safety, and community. Informal recyclers' geographies of survival are connected with \\ urban inequality and are exacerbated by neoliberal trends in the governance of Vancouver's \\ physical, social, and political spaces. We observe that certain users and uses of public space are \\ defined as disorderly or illegitimate, the poor are pushed to the margins of society, and rhetorical \\ urban revitalization and "greening" agendas are prioritized over the needs of the poor in policy \\ making. However, neoliberal trends are inherently contradictory and can change based on local \\ contestation and opposition. Geographies of survival are therefore an important mechanism \\ through which informal recyclers can reclaim city spaces as they resist spatial restrictions and \\ work to maintain their access to necessary resources. We conclude that the geographies of \\ survival lens provides an important perspective on urban power relationships and their spatial \\ dynamics in contemporary Vancouver.
}

\section{Keywords}

informal recycling; neoliberalism; Vancouver, BC; geographies of survival 


\section{Introduction}

In this paper, we argue that an analysis of informal recyclers" "geographies of survival" in Vancouver, BC provides insights to the ways that neoliberal urbanism has impacted the lives and work of informal recyclers and other low-income urbanites in the city. Informal recyclers (locally referred to as "binners") collect items that they can reuse, sell, or return for a refund (i.e. beverage containers in the province of British Columbia are managed under a deposit return system). Most of these workers use informal recycling as a subsistence strategy for supplementing social assistance or other low-paid work. Recyclables and reusable items are usually recovered from waste receptacles on the street or from dumpsters in alleyways, making informal recycling a particularly public activity, and one that is often associated with the stigma of poverty and disorder.

Mitchell and Heynen's (2009) articulation of "geographies of survival” explains that impoverished city residents construct pathways through the urban landscape that "link together places to sleep or rest... locations to eat a meal or forage food, hidden corners of security and safety... and even sometimes such relatively permanent fixtures as homeless encampments or shanty towns" (613). Local manifestations of neoliberal trends, while not totalizing, are an example of an urban force that influences several factors that affect the urban poor. Neoliberal policy interventions act as a major force in the transformation of urban environments, where the redefinition of public space (Brenner et al, 2009) often comes to exclude informal recyclers and other marginalized urban residents. Neoliberalism is a dynamic and unstable process and is susceptible to local resistance due to its contextual embedding in local institutions and practices. Neoliberal governance is therefore not static; rather it touches down in the city as multi-scalar 
adaptable strategies that change based on local contexts of contestation and resistance (Peck et al, 2009; Kiel, 2002; Larner, 2000).

This paper focuses on neoliberal governance as one of the trends that alters informal recyclers' geographies of survival in Vancouver by affecting the governance of public space and the provision of social services. In the context of Vancouver and its Downtown Eastside (DTES; a low-income neighbourhood often framed as being in need of intervention), even wellintentioned policies and programs do not roll out evenly across the urban environment. Instead, we argue that informal recyclers' geographies of survival tend to be increasingly restricted based on the framing and transformation of urban public spaces. Urban change as experienced by Vancouver's informal recyclers is therefore a reflection of the growing physical, social, and political inequality between the city's wealthy and poor residents.

We begin by outlining the theoretical bases of geographies of survival and neoliberal urbanism. We then discuss the methods that we used in the research project informing this paper, followed by an in-depth discussion of results and research outcomes.

\section{Theory}

\subsection{Geographies of survival}

Mitchell and Heynen (2009) describe the geography of survival as "the spaces and spatial relations that structure not only how people may live, but especially whether they may live" ( $p$. 611, italics in original). While their analysis focuses on surviving homelessness (see also DeVerteuil, 2011; Evans 2011; Hodgetts et al, 2012), the concept has been expanded to describe the tenuous spatial relations associated with other survival activities, including food access 
(Heynen, 2009; Heynen, 2010; Miewald and McCann, 2014) and "safer environment interventions" for people who inject drugs (McLean, 2012; McNeil and Small, 2014).

As a concept, geographies of survival draws on the Lefebvrian right to the city, articulated by Purcell (2002) as "a call for a radical restructuring of social, political, and economic relations, both in the city and beyond" (p.101). There is therefore a politicized imperative to the investigations of how people survive in cities, and what factors prevent them from doing so. Many of these analyses identify trends in neoliberalizing cities that endanger the survival of marginalized groups. For example, Mitchell and Heynen (2009) discuss the impact of CCTV surveillance, changes in trespass law, and the criminalization of food sharing in public spaces on homeless individuals' geography of survival in North American contexts. We have also found that neoliberal urbanism in Vancouver poses a threat to the survival of informal recyclers: restrictions on recyclers' lives and livelihoods have increased, leading to more precarious and risky ways of securing access to resources.

\subsection{Neoliberal urbanism}

Neoliberal urbanism is represented by a set of multi-scalar political and ideological practices whereby "rational" political and corporate authorities act to re-regulate everyday urban life by emphasizing individual responsibility, the unrestricted accumulation of capital in a free market, and the deregulation, roll-back, and privatization of public services, public spaces, and socioeconomic intervention (Keil, 2002; Mitchell, 2004; Larner, 2000). Neoliberal modes of governance are a prominent trend in the governance of urban space that contributes to a socially, economically, and spatially unequal landscape within cities. Despite its predominance in mainstream society and policy-making, urban neoliberalism is not a fixed ideology, but a 
phenomenon or process that is contradictory and susceptible to change in response to local contexts of resistance and opposition (Larner, 2000). To this extent, Keil (2002) states, "As a state strategy, urban neoliberalism creates new conditions for the accumulation of capital; yet it also inevitably creates more fissures in which urban resistance and social change can take root" (579).

\subsection{Neoliberal urbanism in Vancouver}

In recent decades, both the Province of British Columbia and the City of Vancouver have developed several political strategies and policies that exemplify the neoliberal processes and practices that Brenner \& Theodore (2002) outline in their analysis of "actually existing neoliberalism" in cities: the restructuring of the welfare state; transformations of the built environment and urban form; reregulation of urban civil society; and re-representing the city. These mechanisms have touched down in Vancouver via cuts to social assistance and public service provisioning (Tremblay, 2007); a real-estate boom, the 2010 Olympic games, and the redevelopment of urban areas towards elite consumption (Barnes et al, 2011); increased criminalization, surveillance, and enforcement of "public disorder" (Berti \& Sommers, 2010); and rhetorical agendas to revitalize and "green" the city (City of Vancouver, 2012). These characteristic elements of neoliberal modes governance act in combination with other urban forces to exacerbate the spatial and social polarization of the city.

In addition to the above understandings of poverty and disorder, recent trends in urban planning and policymaking have promoted urban redevelopment and revitalization projects that exemplify neoliberal shifts in the governance of the city (also see: City of Vancouver, 2000; 2006; 2010; Mason, 2007). These policy plans and their "greening" and "revitalization" rhetoric 
reflect dominant societal narratives that privilege certain uses of space while criminalizing others. Smith (2003) discusses the effect of such urban revitalization agendas, where simultaneous pressures associated with gentrification and ghettoization overlap and create inequality within the community. In this way, the DTES attracts marginalized people because of its concentration of low-barrier services and its accepting community; however, it is simultaneously encroached on by urban redevelopment towards elite consumption and services, and accompanied by the surveillance of impoverished residents. These municipal policies encourage increased "social mix", which Walks \& Maaranen (2008) argue actually acts to further polarize communities and push low-income residents out. Gentrification is a highly contested issue in the DTES. Some authors argue that this type of urban change is very prevalent (Sutherland et al, 2014; Dale \& Newman, 2009; Walks \& Maaranan, 2008; Miewald \& McCann, 2014), while some also suggest that the DTES community has been somewhat successful at keeping gentrifying forces away (Ley \& Dobson, 2008).

The predominant framing of poverty in the city as "disorder" is increasingly influenced by capitalist neoliberal policymaking, but is also informed by other urban forces, such as legacies of colonialism in the city and the DTES. For example, there is a demographic overrepresentation of Aboriginal people among the low-income DTES population, and in the sample of informal recyclers participating in this research. Colonial legacies of impoverishment, abuse, and disenfranchisement have impacted the dynamics of Aboriginal poverty (Wilson and Macdonald, 2010), and the socio-cultural experiences of urban Aboriginal people in Canada is particularly complex (Wilson and Peters, 2005). As Purcell (2002) notes, too a narrow focus on economic issues implies that claims of rights to the city "must challenge the capitalist city rather than challenge, for example the racist city, the patriarchal city, or the heteronormative city" (p. 106). 
We therefore suggest that our analysis of neoliberal urbanism, while revealing important trends in the ways that informal recyclers' geographies of survival are threatened, is by no means a totalizing account of the many social forces that can impact one's ability to survive in the DTES neighbourhood of Vancouver.

\subsection{Geographies of surviving neoliberal urbanism in Vancouver}

In the context of Vancouver, we use geographies of survival as a framework for understanding the impacts of neoliberal urbanism on the well-being of informal recyclers. We argue that there are three means by which neoliberal interventions threaten their ability to work, and therefore to survive. First, public space is a key resource for informal recyclers. The DTES is home to a local community culture where public spaces (e.g. sidewalks, parks) are used by local residents as the "living room" of the neighbourhood (Masuda \& Crabtree, 2010). This streetbased culture is highly contested in Vancouver: on one hand, these public spaces are perceived as sites where homeless and addicted individuals to "participate in unsightly or unruly behaviours" (Masuda \& Crabtree, 2010: 663); on the other hand, these sites are gathering spaces, important in the neighbourhood's role as a "therapeutic landscape", or a place that "offers support, solidarity, and acceptance to marginalized people facing environmental injustice in the inner city (Masuda \& Crabtree, 2010: 656). The use of public space by low-income urbanites has become a focus of neoliberal interventions to the urban sphere, often resulting in reduced access to these spaces of survival.

Second, the ways that public disorder is policed and regulated under neoliberal urbanism have implications for the well-being of informal recyclers. Wardaugh \& Jones (1999) state that in the neoliberal version of poverty, "it is not marginality per se that is dangerous: rather it is the 
visible presence of marginal people within prime space that represents a threat to a sense of public order and orderliness" (112). Marginalized citizens are often made to be invisible in society due to institutionalized neoliberal conceptions of poverty, where adaptations like informal recycling are understood by the public as "disorder" rather than as a "means of survival," rendering these workers unable to meet their basic survival needs without breaking the law (Berti \& Sommers, 2010). Neoliberal governance approaches that frame low-income uses and users of public space as disorderly and dangerous can exacerbate social-spatial polarization and inequality in the city (Brenner \& Theodore, 2002; Berti \& Sommers, 2010; Mitchell, 1997).

Third, the macro-economic scale of neoliberal restructuring has impacts on low-income urbanites through the erosion of the welfare state. Neoliberal approaches to healthcare tend to place the responsibility for one's health and socioeconomic situation on individuals rather than on the social and structural factors that influence the inequitable distribution of health resources in society. This emphasis on individual-level responsibility values a person's financial independence, which has significant implications for health as access to socially determined health resources are framed as an individual rather than societal responsibilities (Raphael et al, 2008). Larner states that neoliberal strategies "encourage people to see themselves as individualized and active subjects responsible for enhancing their own well-being" (2000: 13). Similarly, Isin suggests "citizens are redefined as clients...who are responsible for their own success, health, and well-being" (1998: 582). The dominant socio-political attitude towards impoverished residents as individuals who are not trying hard enough impedes progress toward health equity and poverty reduction because decision-making often reflects the priorities of the more valued or wealthy constituents over low-income clientized groups (Bryant et al, 2011; Raphael et al, 2008; Mikkonen \& Raphael, 2010). 
In the following analysis, we describe the ways that neoliberal urbanism threatens informal recyclers' geographies of survival, identifying a diverse assemblage of actors and mechanisms (e.g. bylaws, provincial laws, municipal policies, and cultural perceptions) that contribute to this trend. It is important to note that many of these actors behave in contradictory ways throughout our analysis (for example, municipal government at times rolls out, mediates, or prevents neoliberal urbanism; see also Mansfield, 2007); for this reason, we suggest that it is instructive to focus on the moments when such actors and agendas cohere (e.g. around framings of public disorder and the retrenchment of the welfare state), rather than working to construe any one actor, policy, or practice as inherently neoliberal.

\section{Material and methods}

This research is based in a series of interviews with informal recyclers $(n=40)$ conducted at the United We Can bottle depot during the summer of 2013. We worked with the depot to administer a survey of informal recyclers onsite regarding an impending location change. This brief survey assessed depot users' concerns regarding the location change. Respondents to the survey were then asked if they were willing to participate in an in-depth follow-up interview. This was therefore a self-selected population of interviewees. The interview themes included recyclers' experiences of the city, and focused on both positive and negative aspects of informal recyclers' health and their experiences of health services in the DTES. As this is a relatively vulnerable respondent group, it was important that research participants were made aware of their right to refuse to answer any questions, and to withdraw from the study at any time. Interviewees were compensated $\$ 10$ in recognition of their time taken away from collecting 
work in order to participate in this study (the compensation amount was in line with stipends paid for other research and workshop participation in the DTES neighbourhood at the time of interview). We also worked to position respondents as experts and knowledge-holders, rather than the objects of study: we were interested in learning from them about their experiences and perspectives. All research activities were conducted under the purview of our institutional Research Ethics Board, and with the requisite approvals.

Key informant interviews were also conducted with local service providers and others working with informal recyclers in the DTES neighbourhood $(n=7)$ in order to understand frontline workers' insights into local health issues. All of the interviews discussed in this paper were conducted by [first author name]. Transcripts were analyzed using a thematic content analysis on NVivo software. This research is part of a larger project investigating the relationship between informal recycling and urban change, and the authors have made multiple field visits to the DTES between 2011 and 2015 between the two of them. The following research also draws on an analysis of municipal policy documents pertaining to both informal recycling and urban change from the early 2000s to present.

\section{Results and discussion}

\subsection{Public space as a survival mechanism}

Vancouver's DTES is a central yet contested site in the survival pathways of informal recyclers. Despite its proximal location to the downtown core and potential for high property values (Ley \& Dobson, 2008), it is a place that has become symbolic of poverty in Vancouver. Furthermore, the DTES and its marginalized residents are framed as synonymous with "public disorder". The neighbourhood and its residents are conflated with urban decay, drug addiction, 
and various stigmatized activities (drug dealing, panhandling, binning, vending, and homelessness), emphasizing perceived social differences between those who live and work in the DTES and those who do not (Berti \& Sommers, 2010; Gordon, 2010).

In particular, informal recyclers are one of the most widely excluded and disempowered groups in society because of their low socioeconomic status and their work with solid waste (Gutberlet, 2010). These workers are highly stigmatized, are often associated with the garbage that that they work with, and are treated as a nuisance or even as criminals (Nas \& Jaffe, 2004; Tremblay, 2007). A number of our respondents reported feeling disrespected or judged based on their "dirtiness" and association with waste, their DTES address, or addictions, and these stigma affected the way that these workers accessed (or avoided) health services and other resources like food and shelter.

The ability to access recyclables and other resalable materials in the public sphere is of paramount importance to these workers. Many of the recyclers also reported other resources in the public sphere, including food, shelter, and sanitation opportunities. Several of our respondents described the "Hastings Shuffle" (also observed by Miewald \& McCann, 2014), whereby daily food acquisition regularly required access to food line-ups and dumpsters into their daily routine in order to access food:

"On the Eastside there's lots of places where you can go at certain hours and I kind of do my routes around the food lines and the different places that have food serving. So I go binning here, stop at a food place, go do some more binning. Like over here, there's another place and they all have different hours, so I can work the whole day and have enough food in me, and I save food for the next day also for food in the morning." (47-year old male, informal recycling for 2 years)

A substantial minority (22\%) of interviewees also reported that they relied on the public trash stream as a source of food:

“Garbage cans. 3 times [a day] - breakfast, lunch, supper." (53-year old male, informal recycling for 3 years) 
Fifteen percent of interviewees reported that they were homeless, indicating the importance of public spaces for social reproduction. Many informal recyclers must meet their sanitation needs in the public sphere as well, regardless of whether or not they had access to such facilities through their current living situations:

"You know, you go to a bar and they don't want you in there and I tried Safeway [grocery store] once too, and I have to go - I just go in the alley." (55year old female, formal recycling for 20 years)

"There aren't [public bathrooms] unless you find a community center somewhere and you go in there and you have bags and bags of bottles so you can't even go in." (53-year old male, informal recycling for 30 years)

Therefore, many low-income urbanites (and informal recyclers in particular) rely on public spaces to earn a living through accessible waste streams, to gain access to food and social services, and sometimes to fulfill other basic needs (including a place to sleep or sanitation needs). However, many of these actions are associated with "disorder" when they are carried out in public, particularly in the downtown area of one of Canada's largest cities.

\subsection{Social construction and policing of public disorder}

Over the past decade, legal mechanisms have been introduced in Vancouver to actively police and displace the "disorder" associated with informal recycling and other aspects of lowincome urban life in the DTES (see Table 1). 
Table 1: Institutional changes that have impacted the inhabitation of public space in Vancouver since 2000

\begin{tabular}{|l|l|l|l|}
\hline Intervention & Year & Scale & Details \\
\hline Vancouver Agreement & 2000 & Municipal & $\begin{array}{l}\text { Plan to improve conditions in the DTES: } \\
\text { emphasized and funded urban } \\
\text { revitalization (over harm reduction or } \\
\text { residents' social needs). }\end{array}$ \\
\hline BC Safe Streets Act & 2005 & Provincial & $\begin{array}{l}\text { Restricted "public disorder" in activities } \\
\text { like panhandling and informal recycling }\end{array}$ \\
\hline $\begin{array}{l}\text { Amendments to the Trespass } \\
\text { Project Civil Society }\end{array}$ & 2005 & Municipal & $\begin{array}{l}\text { Restricted informal recyclers' abilities to } \\
\text { collect waste in urban space }\end{array}$ \\
\hline Solid Waste By-laws & 2006 & Municipal & $\begin{array}{l}\text { Restrictions and fines for informal } \\
\text { recyclers if they are caught removing } \\
\text { refundable materials from bins }\end{array}$ \\
\hline Assistance to Shelter Act & 2009 & Municipal & $\begin{array}{l}\text { Locally known as the "Olympic } \\
\text { Kidnapping Act". Police given the power } \\
\text { to remove homeless residents from the } \\
\text { streets into shelters. }\end{array}$ \\
\hline Greenest City Action Plan & 2012 & Municipal & $\begin{array}{l}\text { Plan to make Vancouver more } \\
\text { sustainable: emphasized urban } \\
\text { revitalization in the DTES in the push } \\
\text { for green urban change }\end{array}$ \\
\hline
\end{tabular}

In 2005, the provincial government introduced the BC Safe Streets Act and amendments to the municipal Trespass Act. These mechanisms of governance were introduced with the intention of tightly regulating informal recycling and panhandling in an effort to decrease "public disorder". Shortly after these initiatives were introduced, Vancouver's former mayor Sam Sullivan developed Project Civil Society, a 2006 municipal policy initiative with the goal of actively targeting “crimes of disorder". This initiative specifically referred to informal recycling as a "problematic behaviour" because of the "general level of chaos and disruption that can result from th[is] activit[y]" (City of Vancouver, 2006: 24). In order to reduce the perceived disorder 
caused by informal recycling, this municipal project suggested making bins less accessible by locking or putting up fences or gates around them, an effort which has become quite commonplace:

"It's getting fewer and fewer, there's more getting locked up and locked up. More now than I’ve ever seen." (53-year old male, informal recycling for 13years)

Informal access to the waste stream is further restricted through solid waste bylaws introduced in the same year. The bylaws (see City of Vancouver, 2006) are enforced with a $\$ 100$ fine if informal recyclers are caught removing refundable materials from recycling bins (Tremblay, 2007). These bylaws increase the stigmatization felt by informal recyclers and can also deter residents and businesses from supporting or forming partnerships with them due to the illegality associated with informal recycling. Locking bins and enforcing bylaws could also be interpreted as a method of reducing exposure to occupational hazards and protecting recyclers from negative health outcomes. However, these actions have been taken without consulting recyclers about potential actions to improve their health. Rather, interviewees who discussed locked bins said that the locks just added difficulty to their collection of recyclable materials and pushed them to obtain materials in more precarious or risky ways. Such innovations in governance that restrict access to the waste stream create tensions in the lives of informal recyclers and in their geographies of survival by limiting their livelihood options.

Street vending is another aspect of informal recycling that is closely connected to the construction of public disorder. For many recyclers, selling reusable and repairable items that they find in the waste stream is an important source of income. Much of this street vending activity is concentrated along and near Hastings Street in the heart of the DTES. However, this activity is largely illegal (outside of the sanctioned Pigeon Park Street Market, discussed below). 
Between 2008 and 2012, 95\% of the city's street vending tickets were handed out in the DTES neighbourhood, with an associated fine of $\$ 250$. Many of these ticketing blitzes occurred in the lead-up to the 2010 Winter Olympic Games, but are still an ongoing issue in the neighbourhood (Pivot, 2012). An interviewee discussed one of several unaffordable tickets that he has received in the neighbourhood, specifically for vending recovered clothing on Hastings Street:

"I got a ticket for doing it out on Hastings here...\$250...we get the most tickets in the DTES, tickets compared to anywhere else, any other neighbourhood... I can't afford to pay that." (48-year old male, binning for 15 years)

This quotation was one of many revealing that tickets for informal recycling are handed out fairly regularly, and also that they are unaffordable for informal recyclers. Most respondents also commented on the injustice and inequality that they experienced in terms of targeted ticketing in the DTES. Pivot Legal Society (a law reform organization focused on addressing poverty, marginalization, and inequality) recently filed a constitutional challenge to Vancouver's vending bylaws, which require a $\$ 800$ permit for street vending. Although the challenge was dismissed in court (thus upholding the bylaw), the presiding judge reduced the ticketing sentence for the four street-vendor claimants from $\$ 250$ to $\$ 1$ each (Griffin, 2014). The municipality has purchased a vacant lot in the neighbourhood with plans to permanently house an indoor market for vendors; there are doubts whether this solution will address the needs of low-income street vendors, or address resistance from nearby business owners and residents who are concerned that a permanent vending site would bring the stigma of poverty with it (King, 2015).

As detailed by Parizeau and Lepawsky (2015), bylaws that police informal recycling activities are also not enforced consistently in Canadian cities, leading to flexibility for potentially compassionate authorities, but uncertainty for informal recyclers. By implementing and enforcing criminalizing bylaws against informal recyclers and locking bins, the municipality 
is paradoxically affecting the viability of its most socially and environmentally successful and self-sustaining poverty reduction project for DTES residents (Dale \& Newman, 2009).

\subsection{Erosion of the welfare state}

Ruckert \& Labonte (2012) discuss the impacts that neoliberal governance mechanisms and the erosion of the welfare state have on the health of urban populations. This shift is evident in British Columbia, where the devolution in government provisioning of health and social services can be seen in the 2001 reduction of the number of regional health authorities from 52 to 5, a "cultural shift" towards business management practices in healthcare, and in budget cuts to services and programs (Teghtsoonian, 2009).

With respect to the lives of informal recyclers, the most salient aspects of welfare state retrenchment include health and social service budget cutbacks, and welfare program reductions. In the DTES, these trends manifest in the rise of contracted community organizations and notfor-profit groups replacing the welfare state model as service providers for the poor. This contracting model has resulted in multiple insecurities for local service providers who are reliant on short-term funding contracts and charitable donations, but are unable to plan or hire for the long-term, and must adhere to neoliberal priorities in their attempts to access these funds (Roe, 2009). Masuda \& Crabtree (2010) discuss the need for health and food provisioning agencies to adhere to austerity politics and dominant understandings of the impoverished "other" in order to access funding: "DTES residents are often communicated as mere numbers...the quantitative results of these programs are then communicated in public relations, grant applications, and reports so as to bolster efforts to secure additional funding in order to maintain services" (660). In this way, neoliberal ideologies concerning funding and contracted low-barrier services can 
perpetuate the clientization of stigmatized residents (a process that is enacted as residents are subjected to lineups and regulations in their efforts to access basic necessities like food; Roe, 2009).

Teghtsoonian (2009) discusses the concept of "responsibilization" in mental health treatment in BC, arguing that there is a strong governmental emphasis on individual-level variables rather than on public policies or wider societal issues. As a result of the responsibilization of health, individuals, families, and workplaces - rather than publicly funded services - are framed as the main resources for those who are dealing with mental illness in British Columbia. A report issued by the Vancouver Police Department echoes calls for increased public funding for mental health, stating that police officers have become society's de facto front line mental health workers, with nearly half of the emergency calls from the DTES and surrounding neighbourhoods involving a mental health issue (Thompson 2010).

Several key informants attributed many of the barriers in service provision to restrictive funding measures:

"I feel like agencies are scrambling over funding, like they're only giving out this much for grants, or this much for this... Instead of us fighting over these little crumbs that are only going to last $\mathrm{X}$ amount of time, you can hire people, but you don't know how long you can keep them. It's hard to maintain staff in that kind of environment... there's turn over all the time." (Community worker)

This quotation highlights how the short-term nature of the current funding model for low-barrier services in the DTES makes it difficult to retain staff and plan for the long-term, while also encouraging inter-organizational competition for funding rather than promoting a cohesiveness among service providers. The most prominent trend that emerged from the key informant interviews was that the short-term contracting model and cuts to local health-promoting 
programs are making the task of supporting the health and well-being of DTES residents increasingly difficult.

Almost all $(95 \%)$ of the interviewees in our study reported that they relied on social assistance. Tremblay (2007) discusses the detrimental social and economic impacts of social assistance re-regulations and cutbacks on the lives of informal recyclers in Vancouver that occurred in the 2000s. Similarly, Bradley et al (2011) and Stuckler et al (2010) found that decreased public spending on social assistance can be directly correlated with worsening health equity in the city. These types of shifts can be seen in Vancouver, where restrictions on eligibility and the stagnation or decrease of welfare rates have had very real impacts on the lives of informal recyclers in terms of their ability to afford basic resources like housing and food. The Carnegie Community Action Project released a hotel and housing report that indicates rents in the DTES are rising faster than the rate of inflation and are quickly becoming unaffordable to residents who depend on welfare payments (Sutherland at al, 2014). These increasing housing costs are especially troubling when considering the welfare rates in $\mathrm{BC}$, which indicate stagnation since 1986 for single employable people, and an overall decrease for those receiving disability payments (Tweedle et al, 2013).

In the context of Vancouver, the erosion of the welfare state is occurring in tandem with rising inequality. Others have described the redevelopment of urban areas towards elite consumption in Vancouver (Barnes et al, 2011; Burnett 2014; Miewald and McCann, 2014), and the DTES is one of the focal points for this type of urban change. In a context of increasing polarization and decreasing social supports, we suggest that informal recyclers' survival will only become more difficult in neighbourhoods like the DTES. 


\subsection{Local contestation: Surviving neoliberal urbanism}

An outreach nurse described the tension between the challenges associated with precarious living and working conditions in the DTES and the ways that informal recyclers manage to cope and survive:

"... a lot of those things [that]contribute to your well being, they [informal recyclers] don't usually have on their side. So its hard to live outside, it's hard to work as hard as they work, and yet on the other hand, they're awesomely resilient." (Outreach nurse)

Vancouver's informal recyclers are therefore not simply victims of neoliberal urbanism; they find ways to cope with and contest the challenges they face in urban spaces by altering their geographies of survival. On the most basic level, these workers individually adapt their geographies of survival to cope with the imposed restrictions on their lives: they avoid surveillance, they build networks of resources and spaces that allow them to meet their needs, and they find service providers who are able to provide the types of support they require.

There are also organizational challenges to both narratives of disorder and the disruption caused by the erosion of the welfare state. As described above, Pivot Legal Society has been an important ally for low-income urbanites in Vancouver in its work to reform laws and policies that disadvantage those living in poverty. Two other examples of organizations that work for and with informal recyclers include the United We Can (UWC) bottle depot and the Pigeon Park Street Market (PPSM).

United We Can is a bottle depot that was founded by and for informal recyclers in 1995, and is run as a social enterprise. In addition to the depot that serves individual recyclers, UWC provides lane cleaning services for the DTES, bike repair services, and the commercial collection of deposit-refundable containers for participating businesses, multi-residential buildings, and schools. In addition to providing employment for DTES residents, it is also an organization that 
advocates for informal recyclers and provides them with a sense of community (Dale \& Newman, 2006; Tremblay, 2007). UWC has received municipal funding and support, particularly with the development of a new business plan and the search for a relocation site for the depot (City of Vancouver, 2010). UWC was relocated in 2014 to a site just outside of the DTES that provides more space for organization and storage, hand-washing and bathroom facilities for recyclers, and a streamlined cash-out system. While some observers have characterized this move as a displacement due to the redevelopment of the original building, our contacts at UWC describe the redevelopment as an opportunity to find a more appropriate space with the logistic support of municipal actors. In other words, they saw this as an opportunity to survive (and even thrive).

The weekly Pigeon Park Street Market at Hastings Street and Carrall Street is another important resource that allows marginalized informal recyclers to have a voice in Vancouver's political space. Despite the market's protest roots, the coordinators now work with the city, holding a temporary permit to the Pigeon Park space on Sundays between 10am-4pm, and gaining access to a small lot on Hastings Street for storage and the potential to run a small market during the week. The municipal support of the PPSM through permits and the use of an urban lot indicate support for this marginal population of street vendors, yet this is complicated by ongoing tensions over who will fund or provide basic necessities for the market (i.e. access to sanitation facilities, waste pick-up, electricity, water).

In addition to organizations that work on issues of direct relevance to informal recycling activities, interview respondents identified other organizations that contribute to their survival, including the Insite safe injection site (unique in Canada for its legal status; see Milloy et al, 2008 for a discussion of the life-saving success of this initiative); VANDU (Vancouver Area 
Network of Drug Users: an advocacy group run by and for drug users, both current and former), and the Carnegie Community Centre Association (an organization housed at the heart of the DTES that provides both social services and advocacy initiatives, including the Carnegie Community Action Project working on housing, income, and land use issues in the DTES).

When informal recyclers and key informants were asked which interventions they thought could improve the well-being of these workers, the primary response from both groups indicated that changes to societal attitudes should be the biggest priority. An outreach nurse explains:

"As a society we have to change our attitudes about people, about what our responsibility is for people, how much control people actually have over their circumstances. And then we have to move to make some real, structural changes in the world out there" (Outreach Nurse).

UWC's founder Ken Lyotier expressed a similar opinion in the Vancouver Sun: he hoped that the new ReturnIt garbage bins that separate recyclables from the waste stream and allow for easy collection by informal recyclers "might result in a change in public attitudes" about Vancouver's informal recycling community (V'Inkin Lee, 2012). By raising awareness of informal recyclers and designing bins that facilitate their presence in high-traffic public areas, the city may be improving public knowledge of, and acceptance for, these informal workers.

\section{Conclusions}

Our analysis of the geographies of informal recyclers' survival has demonstrated that neoliberal urban interventions threaten their ability to work and live in the DTES neighbourhood. Dominant understandings of waste and poverty are linked with neoliberal ideologies and have contributed to the criminalization of informal recycling, vending, and other poverty-related acts and behaviours, the stigmatization of the poor, and the clientization of impoverished residents who require low-barrier services in order to support themselves. Vancouver's informal recyclers 
experience inequity in urban spaces due to their association with "disorder" and the waste that they work with, and the policing of "disorder" has limited their access to public spaces. These restrictions on informal recyclers' lifestyles and livelihoods affect the way that these workers access resources through increasingly restricted geographies of survival. In this way, the experiences of the Vancouver's informal recyclers exemplify the uneven rollout of even wellintentioned governance mechanisms in the city. As an analytical framework, geographies of survival provides a spatial perspective on the impacts of neoliberal urbanism on low-income urbanites. In this case, we have observed the constriction of both physical and social spaces that informal recyclers use for their survival in the urban sphere. The geographies of survival framework also emphasizes the importance of political spaces where informal recyclers' interests can be voiced and promoted.

Neoliberal trends are inherently contradictory and can change based on local contestation and opposition. Geographies of survival are therefore mutable and responsive in the ways that informal recyclers reclaim city spaces, resist restrictions, and devise coping strategies to maintain their access to necessary resources. In this way, as "new challenges present themselves in the urban landscape, people in need as well as activists and service providers invent new strategies for coping — strategies that sometimes directly confront the relations of power that structure everyday life, and at other times seek only to make life tolerable within them" (Mitchell \& Heynen, 2009: 613).

On a larger scale, United We Can and the Pigeon Park Street Market are examples of local activism and opposition to the criminalization of disorder that have attempted to bring marginalized residents out of the urban shadows and back into public spaces in the urban sphere. It is important that civil society actors continue to push for these local governance mechanisms 
to include long-term planning and support, rather than short-term funding contracts and support schemes. Voices from the margins must also be included in the prioritization of local issues and the governance of the city in order to meaningfully change societal attitudes toward informal recyclers and their work (see also Beaton et al., 2015). By reframing predominant societal constructions of "disorder" and including marginalized residents in the governance of urban spaces, the uneven rollout of policies that restrict informal recyclers' geographies of survival can be more effectively shifted toward urban pathways that promote equality for all residents of the city. We believe that researchers also have a role in promoting the voices of those marginalized groups often excluded from policy decisions that impact them the most (Boyd, 2008).

As Dale \& Newman (2009) argue, although the revitalization of the city does provide environmental and economic benefits, it is necessary for city officials and developers to be mindful about "who this development is for, who is poorly served by the current trends, and what the social costs are of displacement of existing residents" (679). When policymakers prioritize the use of urban spaces towards more "legitimate" or privileged uses and physically exclude and enact surveillance towards others, those who are deemed to use public space in a disruptive or disorderly way must cope or push back by further diversifying their work practices and livelihood strategies, or by accessing resources in more precarious and risky ways.

\section{Acknowledgements}

Funding for this research was provided by [to be inserted after blinded review process]. Research assistance was provided by [to be inserted after blinded review process]. 


\section{References}

Barnes, T., T. Hutton, D. Ley, and M. Moos. 2011. "Vancouver: Restructuring Narratives in the Transnational Metropolis.” In L.S. Bourne, T. Hutton, R.G. Shearmur, and J. Simmons (eds.), Canadian Urban Regions: Trajectories of Growth and Change. Don Mills, ON: Oxford University Press: 291-327.

Beaton, S., T. Cain, H. Robinson, V. Hearn, and ThinkPlace. 2015. An insight into the experience of rough sleeping experience in central Auckland. Retreived from: http://www.aucklandcitymission.org.nz/uploads/file/Research/An\%20insight\%20into\% 20the\%20experience $\% 20$ of\%20rough\%20sleeping\%20in\%20Central\%20Auckland.pdf

Berti, M \& Sommers, J. 2010. "The streets belong to people that pay for them": The spatial regulation of street poverty in Vancouver, British Columbia. In Eds: Crocker, D \& Johnson, V.M. Poverty, Regulation, \& Social Justice: Readings on the criminalization of Poverty. 60-73. Fernwood Publishing: Black Point.

Boyd, S.C. 2008. Community-based research in the Downtown Eastside of Vancouver. Resources for Feminist Research, 33(1/2): 19.

Bradley, E.H., Elkins, B.R., Herrin, J., \& Ebel, B. 2011. Health and social services expenditures: Associations with health outcomes. BMJ Quality and Safety, 10: 826-831.

Brenner, N., Marcuse, P., \& Mayer, M. 2009. Cities for people, not for profit: Introduction. City, 13(2-3): 176-184.

Brenner, N \& Theodore, N. 2002. Cities and the geographies of "actually existing neoliberalism". Antipode, 34(3): 349-379.

Bryant, T., Raphael, D., Schrecker, T. \& Labonte, R. 2011. Canada: A land of missed opportunity for addressing the social determinants of health. Health Policy, 101: 44-58.

Burnett, K. 2014. Commodifying poverty: gentrification and consumption in Vancouver's Downtown Eastside, Urban Geography, 35(2): 157-176.

City of Vancouver. 2000. The Vancouver Agreement. Retrieved from: http://www.vancouveragreement.ca/the-agreement/

City of Vancouver, 2006. Project Civil City. Retrieved from: http://www.samsullivan.ca/pdf/project-civil-city.pdf 
City of Vancouver. 2010. Survey of low-income housing in the downtown core. Housing policy: Community services group.

City of Vancouver. 2012. Greenest city action plan. Retrieved from: http://vancouver.ca/files/cov/Greenest-city-action-plan.pdf

Dale, A. \& Newman, L. 2006. Sustainable community development, networks and resilience. Environments Journal, 34(2): 17-27.

Dale, A. \& Newman, I. 2009. Sustainable development for some: green urban development and affordability. Local Environments, 14(7):669-681.

De Verteuil, G. 2011. Survive but not thrive? Geographical strategies for avoiding absolute homelessness among immigrant communities, Social \& Cultural Geography, 12(8), 929-945.

Evans, J. 2011. Exploring the (bio)political dimensions of voluntarism and care in the city: The case of a 'low barrier' emergency shelter, Health \& Place, 17:24-32.

Gordon, T. 2010. Understanding the role of law-and-order policies in Canadian cities. In Eds: Crocker, D \& Johnson, V.M. Poverty, Regulation, \& Social Justice: Readings on the criminalization of Poverty, 33-41. Fernwood Publishing: Black Point.

Gutberlet, J. 2010. Waste, Poverty and Recycling Editorial, Waste Management, 30: 171-173.

Griffin, K. 2014. “Judge dismisses challenge of Vancouver's street vending bylaw.” September 23, The Vancouver Sun. Accessed online: www.vancouversun.com/news/Judge+dismisses+challenge+Vancouver+street+vending +bylaw/10228324/story.html\#ixzz3dFsF5Ld9

Heynen, N. 2009. Bending the Bars of Empire from Every Ghetto for Survival: The Black Panther Party's Radical Antihunger Politics of Social Reproduction and Scale, Annals of the Association of American Geographers, 99(2):406- 422.

Heynen, N. 2010. Cooking up Non-violent Civil-disobedient Direct Action for the Hungry: 'Food Not Bombs' and the Resurgence of Radical Democracy in the US, Urban Studies, 47(6): 1225-1240.

Hodgetts, D. Stolte, O., Nikora, L.W. \& Groot, S. 2010. Drifting Along or Dropping into Homelessness: A Class Analysis of Responses to Homelessness, Antipode, 44(4):12091226. 
Isin, I.F. 1998. Governing Toronto without government: Liberalism and neoliberalism. Studies in Political Economy, 56 (Summer): 169-191.

Keil, R. 2002. "Common-sense" neoliberalism: Progressive conservative urbanism in Toronto, Canada. Antipode, 34(3): 578-601.

King, D. 2015. "Vancouver's street vending solution?” May 15, The Georgia Straight. Accessed online: http://www.straight.com/news/452416/doug-king-vancouvers-street-vendingsolution

Larner, W. 2000. Neo-liberalism: Policy, ideology, governmentality. Studies in Political Economy, 63 (Autumn): 5-25.

Ley, D. \& Dobson, C. 2008. Are there limits to gentrification? The contexts of impeded gentrification in Vancouver. Urban Studies, 45(12): 2471-2498.

Mansfield, B. 2007. Property, Markets, and Dispossession: The Western Alaska Community Development Quota as Neoliberalism, Social Justice, Both, and Neither. Antipode, 39(3): 479-499.

Mason, M. 2007. Collaborative partnerships for urban development: A study on the Vancouver Agreement. Environment and Planning A, 39: 2366-2382.

Masuda, J.R \& Crabtree, A. 2010. Environmental justice in the therapeutic inner city. Health and Place, 16: 656-665.

McLean, K. 2012. Needle exchange and the geography of survival in the South Bronx, International Journal of Drug Policy, 23:295-302.

McNeil, R. \& Small, W. 2014. 'Safer environment interventions': A qualitative synthesis of the experiences and perceptions of people who inject drugs, Social Science \& Medicine, 106:151-158.

Miewald, C. \& McCann, E. 2014. Foodscapes and the geographies of poverty: Sustenance, strategy, and politics in an urban neighbourhood. Antipode, 46(2): 537-556.

Mikkonen, J., \& Raphael, D. 2010. Social determinants of health: the Canadian facts. Toronto: York University School of Health Policy and Management.

Milloy M-JS, Kerr T, Tyndall M, Montaner J, Wood E. 2008. "Estimated Drug Overdose Deaths Averted by North America's First Medically-Supervised Safer Injection Facility.” PLoS ONE 3(10): e3351. doi:10.1371/journal.pone.0003351 
Mitchell, D. 1997. The annihilation of space by law: The roots and implications of anti-homeless laws in the United States. Antipode, 29(3): 303-335.

Mitchell, D \& Heynen, N. 2009. The geography of survival and the right to the city: Speculations on surveillance, legal innovation, and the criminalization of intervention. Urban Geography, 30(6): 611-632.

Mitchell, K. 2004. Crossing the Neoliberal Line: Pacific Rim Migration and the Metropolis. Philadelphia, PA: Temple University Press.

Nas, P., \& Jaffe, R. 2004. Informal waste management: shifting the focus from problem to potential. Environment, Development, and Sustainability, 6: 337-353.

Peck, J., Theodore, N., \& Brenner, N. 2009. Neoliberal urbanism: Models, moments, mutations. SAIS Review, 29(1): 49-66.

Pivot. 2012. Backgrounder on by-law enforcement in Vancouver's Downtown Eastside. Retrieved from: http://www.pivotlegal.org/vandu_and_pivot_allege_discrimination_by_vpd_in_by_law _ticketing

Parizeau, K. \& Lepawsky, J. 2015. Legal orderings of waste in built spaces, International Journal of Law in the Built Environment, 7(1): 21-38.

Purcell, M. 2002. Excavating Lefebvre: The right to the city and its urban politics of the inhabitant, GeoJournal, 58: 99-108.

Raphael, D., Curry-Stevens, A. \& Bryant, T. 2008. Barriers to addressing the social determinants of health: Insights from the Canadian experience. Health Policy, 88: 222-235.

Roe, G. 2009. Fixed in place: Vancouver's Downtown Eastside and the community of clients. BC Studies, 164: 75-101.

Ruckert, A \& Labonte, R. 2012. The global financial crisis and health equity: toward a conceptual framework. Critical Public Health, 22(3): 267-279.

Smith, H. 2003. Planning, policy, and polarization in Vancouver's Downtown Eastside. Tijdschrift voor Economische en Sociale Geografie, 94(4): 496-509.

Stuckler, D., Basu, S., and McKee, M., 2011. Budget crises, health, and social welfare programs. British Medical Journal, 341: 77-79. 
Sutherland, R., Swanson, J., \& Herman, T. 2014. No place to go: Losing affordable housing and community. Carnegie Community Action Project's 2013 Hotel Survey and Housing Report. Retrieved from: http://ccapvancouver.files.wordpress.com/2014/02/ccap-hoteland-housing-report-2013.pdf

Teghtsoonian, K. 2009. Depression and mental health in neoliberal times: A critical analysis of policy and discourse. Social Science and Medicine, 69: 28-35.

Thompson, S. 2010. Policing Vancouver' mentally ill: The disturbing truth. For: The Vancouver Police Board. Retrieved from: https://vancouver.ca/police/assets/pdf/reportspolicies/vpd-lost-in-transition-part-2-draft.pdf

Tremblay, C. 2007. Binners in Vancouver: A socio-economic study on binners and their traplines in the Downtown Eastside. MA Thesis, University of Victoria.

Tweedle, A., Battle, K., \& Torjman, S. 2013. Welfare in Canada. The Caledon Institute of Social Policy. Retrieved from: http://www.caledoninst.org/Publications/PDF/1031ENG.pdf

V'Inkin Lee, M. 2012. Vancouver invites binners to participate in new recycling plan: Public drink container recepticles designed with city's salvagers in mind. The Vancouver Sun, August 14, 2012. Retrieved from:

http://www.vancouversun.com/technology/Vancouver+invites+binners+participate+rec ycling+plan/7090625/story.html

Walks, R.A. \& Maaranen, R. 2008. Gentrification, social mix, and social polarization: Testing the linkages in large Canadian cities. Urban Geography, 23(4): 293-326.

Wardhaugh, J. \& Jones, J. 1999. Begging in time and space: 'Shadow work' and the rural context. In Eds: Dean, H. Begging Questions: Street-level economic activity and social policy failure. The Policy Press: University of Bristol. p101-120.

Wilson, D. \& MacDonald, D. 2010. The Income Gap Between Aboriginal Peoples and the Rest of Canada. Canadian Centre for Policy Alternatives Report. Retrieved from: https://www.policyalternatives.ca/publications/reports/income-gap-between-aboriginalpeoples-and-rest-canada

Wilson, K. \& Peters, E. 2005. 'You can make a place for it': remapping urban First Nations spaces of identity, Environment and Planning D: Society and Space, 23: 395-413. 